\title{
FLASHCARD AS A MEDIA TO IMPROVE STUDENTS' WRITING SKILL IN DESCRIPTIVE PARAGRAPH
}

\author{
M. Lathif Musyaffa' \\ lathifmusyaffa2@gmail.com \\ English Language Education Department, Faculty of Teacher Training and Education, Universitas Islam \\ Lamongan
}

\begin{abstract}
The main purpose of this research is to know the improvement of students' writing skill in descriptive paragraph through flashcard media. This research was conducted at SMP "Empat Lima" Karanggeneng. This research is a classroom action research which consisted of two cycles. This study was carried out on February until May 2020. The subjects were the seventh grade students of SMP "Empat Lima" Karanggeneng, Lamongan. The data were collected by holding the test, interviewing, observing and distributing the questionnaire. The instruments that have been used are writing paragraph rubric, interview guideline, observational note and questionnaire sheet. The data that were used in this research are qualitative dan quantitative. This study used democratic validity, outcome validity, catalytical validity, process validity and dialogic validity as the validation. Then, the reliability of this study were time and investigator triangulation. There were several steps in this research implememntation, they are identifying the problems, planning, acting, observing and reflecting. The results showed that the use flashcard media in writing has been able to improve students' writing skill. According to the qualitative data, the students were enjoy and enthusiastic with the implementation of flahcard media in writing lesson. The They also felt easier to make a descriptive paragraph through this media. According to the quantitative data, the students' main score was improved in the each cycle.
\end{abstract}

Keywords: : Flashcard, writing skill.

\section{INTRODUCTION}

An essential thing that must be mastered by everyone is language. By using language, humans can interact with the others through communication. It relates with Keraf $(1997: 1)$ opinion that language is a means of communication between members of the community in the form of a symbol of sound produced by the speech organ (Rabiah, 2012, p. 6).

English is one of languages which most spoken in the world because English is an international language. Brumfit (2001) states that "English is an international language that it is the most widespread medium of international communication" (Arumawati, 2018, p. 2). In Indonesia, English is considered very important to be mastered by people. This is proven by making English as one of the main subjects in junior high school until university.

There are four major skills that must be mastered in English, they are 
listening, speaking, reading and writing. Those skills are related to each other and cannot be independent. Therefore, learners need to master all of them. This is following by The Regulation Minister of National Education number 23 of 2006 which is about the competency standard of graduate for primary and secondary levels in English. One of skills which have to be mastered is writing.

Writing is one of the productive skills that must be mastered by English learners because it is so important to express and develop our knowledge. Some experts define writing variously. According to Gould, DiYanni, and Smith (1989) writing is a creative act, the act of writing is creative because its requires to interpret or make sense of something: an experience, a text and an event (Tomtowi, 2019, p. 164). On the other hand, Brown defines that writing is a thinking process. In addition, he says that writing can be planned and given with an unlimited number of revisions before its release. He also states that writing is a two-step process, the first process is figuring out the meaning and the second process is putting the meaning into language. Writing represents what people think. It is because the writing process reflects things, which stay in the mind (Brown, 2001, p. 336). Based on the definitions above, it can be concluded that writing skill is a productive process in language that must be mastered by language learner and has some process to done it, the processes are planning, acting and revising.

Based on the definition above, it is known that writing consists of some processes. In this case, the process of writing has roughly four steps; the first step is create some ideas(prewriting), the second step is organizing the idea(organizing), the third step is writing a rough draft(writing) and final step is polishing the rough draft by editing it and making revisions(polishing) (Oshima and Hogue, 2007, p. 15-18). 
There are several forms in writing. one of them is writing a paragraph. According to Oshima and Hogue (2007, p. 3) Paragraph is a group of related statements that writer develops about a subject. The first sentence states the main idea or specific point of the topic and the rest of the sentences in the paragraph support the first sentence or main idea. Descriptive paragraph is the one of paragraph form. It is the easiest paragraph form for most people. So, it is appropriate if taught to young learners. Descriptive paragraph a kind of paragraph which appeals to the sense, so it tells how something looks, feels, smells, tastes and sounds. A good description is a word picture which is the reader can imagine about the object, place or person that described (Oshima and Hogue, 2007, p. 61).

As it is know writing is a difficult skill for most people, including English learners. Richard and Renandya (2002) stated that "writing is the most difficult skill for the second language and foreignlanguage learners. Furthermore, they claim that writing is not only generating and organizing ideas of our mind, but also translating these ideas into a readable text." It is suitable with the condition in indonesia that writing is as a foreign language (Arumawati, 2018, p. 2).

Bryne (1988) has divided the problems that make writing difficult into three categories. The first is Linguistic Difficulty. It is about some linguistics aspect like grammar, vocabulary, language use and choice of sentence in writing must have fully monitored. The second is Physiology Difficulty, which more focuses on the writer's difficulty because there aren't direct interaction and feedback from the reader when they are writing. This difficulty more focuses on the difficulty in developing written material or content of the composition. The third is Cognitive Difficulty. Writing has to be thought 
through formal instruction like spelling, punctuation, capitalization and paragraphing (Pratiwi, 2012, p. 3).

.The difficulties of writing that is mentioned above also found in SMP "Empat Lima" Karanggeneng when the researcher conducted a pre-test. Based on the researcher's findings through a preliminary study during English lesson on the seventh grade of that school, He found several problems that were probably as an obstacle in learning writing. Some problems came from the students and the teacher. The problems which from the teacher sides: (1) the teacher gave the material based on the book, for example the teacher just gave a short explanation from the book and then he asked students to finish the test from it (2) The teacher used the lecture method which is very monotonous in studying English. The monotonous process of learning made students bored to learn. The problems did not only come from the teacher but also students' sides: (1) The students were passive in class during the teaching and learning process., (2) The students were noisy and talked each other when the teacher explained the materials., (3)The students felt difficult to catch the teacher's explanation, there were no variations in teaching and learning process, so the students felt bored during teaching process in the class., (4) The students have no motivation enough to learn about English especially in writing, they think that writing is difficult to practice.

The problems above must be solved because writing skill is important for everyone. There are many occupations that require with writing skills for their future, such as journalist, blogger, copywriter and lecturer. Based on the result of preleminiray study, the researcher will do this research at that school. The researcher tries to introduce a new media to teach English in that school, especially 
in writing. So, teaching and learning process can be more varied.

In this case, the media that was used by researcher is flashcard. Flashcard is a large size card, usually using a slightly thick A4 paper containing images or words. Usually flash cards are grouped according to type and class, such us groups of images of a person, food, fruit, vegetable, transportation and clothing. Flash cards are usually used to memorize vocabulary, but flashcards can also be used to describe items according to pictures, for example on the flash card there is a picture of an apple, from that picture we can describe based on colour, taste, nutrition and others (K. E. Suyanto, 2010, p. 109).

There are some previous studies which related to this research. The first is the research has done by Saputri (2017) with the tittle "Improving Students' Speaking skill Through Flash Card in Descriptive paragraph at the Eighth Grade of Mts N Ngemplak Boyolali in
Academic Year of 2016/2017" that research presents about the significance of student' speaking skill after applied flash card media. She used the flash card media to teach speaking in descriptive paragraph in order to improving the student ability in speaking, because through this media students have more motivation to learn English especially in speaking skill than using conventional methods (Aswinda Saputri, 2017). The second is the research has done by Muttahidah (2011) with the tittle 'Improving Student' Vocabulary Trough Vocabulary Card", this research was conducted at the first grade of Mts. Nurul Falah Pondok Aji Ciputat, Tangerang. She used flash card media to teach vocabulary, because through this media the students more have enthusiastic and easier in learning vocabulary (Muttahidah, 2011).The third is the research has done by Apriliani (2016) with the tittle "A Study of Flash Cards in Teaching Vocabulary for 
seventh Grade Students at Mts. Negeri II

Surakarta in Academic Year of

2015/2016". She used flash card media to

teach vocabulary, because she wants to know the effectiveness of using flash card media in teaching English, especially in vocabulary (Apriliani, 2016).

Based on the three previous studies above, it can be seen that those researchers have the similarities in this research. Those three studies focused on teaching English by using flash card media but they just implemented it on teaching vocabulary and speaking. In this study, the researcher try to implement the flashcard media in teaching writing in order to improve the students writing skill.

\section{RESEARCH METHOD}

This research is a classroom action research because the research focuses on a particular problem and a particular group of students in a certain classroom, it is a type of action research.
In this case, the researcher used collaborative action research model that suggested by Kemmis and Taggart, which consists of four steps namely: planning, acting, observing, and reflecting (Burns, 2009, p. 9). this is called "collaborative" because the researcher collaborated with his collaborator in conducting this research

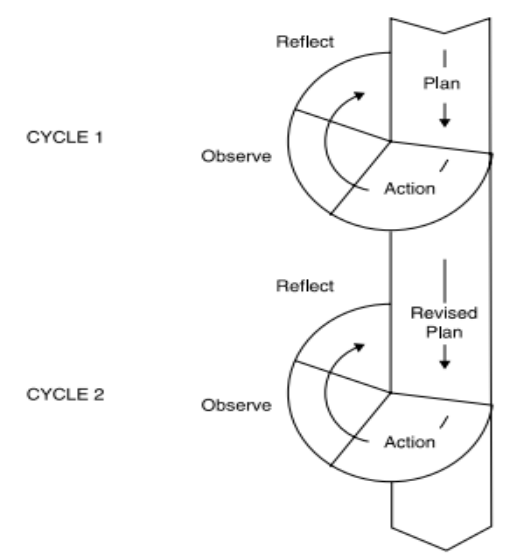

Figure 2: The Cyclical Action Research model based on Kemmis and Mc Taggart (1988).

The subjects of this research were the seventh grade students of SMP "Empat Lima" karanggeneng, Lamongan in the academic year 2019/2020. The research implemented for more than three months, start from February until May 2020. 
The researcher conducted this research into two cycles and every cycle has 4 steps. It was based on Kemmis and Taggart model. They are: Planing, acting, observing and reflecting.

\section{Planning}

In this phase, the researcher and collaborator prepare everything that is needed when carrying out the action.

\section{Acting}

After planning, the reseacher with collaborator implement the action to the students. in this case the focus is only on the use of flashcard media in improving the ability to write descriptive paragraphs of students. The acting steps are as follows simply:

\section{Observing}

In this phase, the researcher observes the activities which were happening during the teaching and learning process. The researchers write all of the activities in the observation notes relate to the teaching and learning process

\section{Reflecting}

In this phase, the researcher and collaborators try to analyze data from observations and actions. after that the researchers evaluated it. after this phase is fulfilled, the researcher will design the next cycle by revising the plan.

The data collection techniques that used in this research is qualitative data (experience-based) and quantitative data (number-based). The qualitative and quantitative data can be used together if the object is same but has a different purpose.The qualitative data consisted of observation, interview and documentation. On the other side the quantitative data used test and questionnaire. Then, the instrument that used in collecting data were observational notes, interview guidline, questionnaire sheet, students' worksheet and writing rubric. The writing rubric that has been used is paragraph 
writing rubric developed by Oshima and Hogue.

To analyze the data, the researcher used qualitative and quantitative techniques.The qualitative data had been analyzed by using Mc.Kernan technique in Burn (2009, p. 104-106); There are five steps: Assembling the data, coding the data, comparing the data, building intrepetation and reporting the outcome. On the other hand, the quantitve data has been analyzed by using the following formulas:

In analyzing test, there are three formulas used: First, the researcher finds out the average score of students. Second, He tries to get the precentage of students who has passed the standard minimum criterion (KKM: 70). Third, He identifies the improvment of students score after treatment.

The formula by (Sudijono, 2014, p. 80):

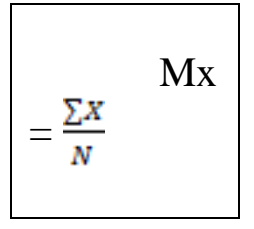

$\mathrm{Mx}=$ Mean (average)

$\sum X=$ Number of score

$\mathrm{N}=$ Number of cases

The formula by (Sudijono, 2014, p. 43):

$$
\mathrm{p}=\frac{f}{N} \times 100 \%
$$

$\mathrm{p}=$ the class percentage

$\mathrm{f}=$ total percentage score

$\mathrm{N}=$ Number of cases

The formula by Sujana (2002) in (Muttahidah, 2011):

$$
P=\frac{y 1-y}{y} \times 100 \%
$$

$\mathrm{P}=$ the percentage of students'

improvment

$y=$ pre-test result

$\mathrm{y} 1=$ Post-test 1 
In analyzing the questionnaire, the researcher used likert scale in order to measure the students' opinion after the implementation in any categories. In this case, the researcher used five gradations, it started from strongly agree until strongly disagree which suggested by Sugiyono (2015, p. 93)

\section{Validity and Reliability of the Data}

In quantitative educational research, validity is an important criterion in evaluating the quality of research. In this case, the researcher uses the Burns' concept in fulfilling the criteria of research validity. According to her, it is divided into five points; democratic validity, outcome validity, process validity, catalytic validity, and dialogic validity (Burns, 1999, p. 161).

In order to obtain the trusttworthiness of this research, the researcher used time and investigator triangulation as the research triangulations. According to Burns (1999) the purpose of triangulation is to gather multiple perspectives on the situation being studied.

Classroom action research can be called success when it passes the criteria. Arikunto (2002) stated that classroom action research will be successful when $80 \%$ of students get a score according to what researchers expect. In this case, the researcher and his collaborator agreed that this research was considered succesful if $80 \%$ of students has passed the KKM (Mudiyatun, 2015, p. 3).

\section{FINDINGS AND DISCUSSION}

In implementing this research, there were some factual data which have found in several activities. It will be described below:

$$
\text { Before implementing the }
$$

flashcard media in teaching writing, the researcher conducted an observation and some interview through a preliminary study in order to identfying the problem, the researcher found some problems during the English lesson on seventh grade 
of SMP "Empat Lima" Karanggeneng.

First, some students get bored during the lesson, it was because the learning process running monotonously. Then, the researcher also found that the students got the difficulties in understanding the English material. It is because they did not understand about the meaning of material. Besides having held an observation and some interviews, the researcher also held a pre-test to measure the basic competence of students in writing descriptive paragraph. According to the result of the pre-test, the data showed that the avarage score in seventh grade of SMP "Empat Lima" is 50,28. Meanwhile, the English teacher states that the minimum of standard criterion competencies (KKM) of English subject is 70 (seventy); It means that was under of KKM. Then, there were only 7 students (17.95\%) who passed the KKM, it means that there were 32 students who need more treatment.
After identifying the problems, the researcher implemented the falshcard media by following the research procedure (planning, acting, observing and reflecting). This research has implemented into two cycles.

\section{Cycle 1}

Based on the result of preliminary study, the researcher with the teacher (as a collaborator) arranged the planning. The plan was included of lesson plan, teaching material, and media. In the other hand, the researcher and his friend (as a second collaborator) also prepared the instruments, such us observation notes, camera and etc.

After arranging the planning, the researcher and his collaborators implemented the flashcard media in acting phase. The cycle 1 was done on March $3^{\text {rd }}$, $4^{\text {th }}$ and $10^{\text {th }} 2020$. The implementation was based on the lesson plan.

During the acting phase, the researcher also conducted the observation. 
In this case, the observer was the English teacher. Based on that observation there were some positive and negative findings. For example: The lesson was more active and the Teacher came on time (positive findings); Some students felt shy to ask and not paying attention (negative findings).

After the observation, the researcher held test in order to measure the students writing skills after the treatment. The data showed that the students score has increased but the result was unqualified with the success criterion of classroom action research. The average score was 72.12, there were 29 students(74.35\%) has passed the KKM and the students score have increased $43.43 \%$ compared to pre-test score.

The last, the researcher conducted the reflecting phase based on the data that have found in acting and observing phase. Based on the data above, it concluded that the action of cycle 1 was not success enough. Because the students score was under the criteria and there were some negative findings that can be evaluate. So, the researcher and his collaborator decided to continue the cycle in order to make a better improvement of the students' writing skill and this classroom action research could be succeed.

\section{Cycle 2}

Based on the reflection in the cycle 1, The researcher and his collaborators concluded some revisions from the cycle 1 into cycle 2 , they are: (1) The teacher must give explanation as simple as possible, (2) The teacher must more firmly in teaching, (3) The teacher must more be covered the class, (4) The teacher must adding some material that were needed. After decided the problems, the researcher and his collaborator planned the next cycle by establishing a lesson plan, planning the media and preparing the material. After the plan was done, 
surprisingly, the school activities were closed and replaced by studying at home because of coronavirus pandemic. So, they remodel the lesson plan into online class form.

Then, the researcher conducted the acting phase. The action of the cycle 2 was done on April $28^{\text {th }}, 29^{\text {th }}$ and May $5^{\text {th }}$ and $6^{\text {th }}$ 2020. The implementation was done online through social media group and the learning material formed of summaries sheet and videos.

On the other hand, the researcher also conducted some observations during the implementation in each meeting. Although at the first meeting there were some problems because the learning was done online, the observer has found that there were some improvments in students understanding. It was also proven with the improvement of students score on cycle 2 test. The data showed that the avarage score of students was 79,94, the percentage of students who passed KKM was $92,30 \%$ (36 students) and the students score have increased $58.99 \%$ compared to pre-test score.

Based on the observations, the students score has passed the criterion of success action research. So, the researcher and his collaborators decided to stop the research in reflecting phase.

\section{The Implementation of Using Flashcard}

\section{in Teaching Writing}

The implementation of fashcard media in teaching writing descriptive paragraph was running well. There were some adventages during and after the implementation of flashcard. They are: (1) The students were more active, (2) The students' motivation improved, (3) The students more interested in learning writing, (4) The students' score improved.

\section{The Improvement of Students' Writing}

\section{Skill by Using Flashcard}

Based on the result of the test above, the student' scores have increased in each cycle. It means that the students 
writing skills has improved. In the pre-test, the average student scores were only 50.28, after implementation in the first cycle the average of student scores increased to 72.12 . Then, the average student scores increased again to 79.94. Accordingly, the number of students who passed KKM also increased in each cycle. In the pre-test, there were only 7 students who passed the KKM. That means only $17.95 \%$ of all students. Then, in the second cycle this number has increased to 29 students, it means there are $74.35 \%$ of students who have passed the KKM. in the last cycle, it passed again into $92.30 \%$ or 26 students.

In the data above also explained the increase of student' average scores in percentage on the each cycle. The first cycle showed the increase of it was $43.43 \%$ compared with pre-test results. In the accordance with it, the second cycle was increased into $58.99 \%$ compared to the pre-test. That means from the first cycle to the second cycle there was an increase of $15.56 \%$.

In simply, the improvment of students' writing skills can be seen in the following chart.

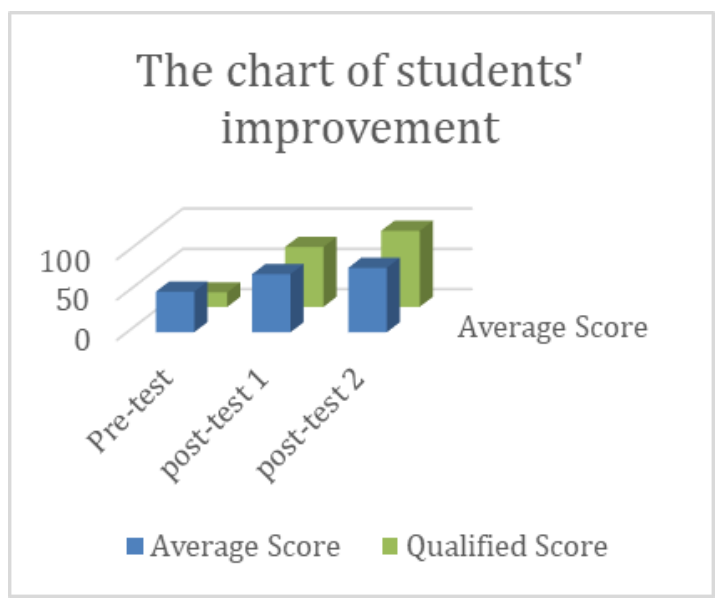

Figure 3: The students' Improvment

The comparison of students' improvement in each cycle can be seen on the chart below:

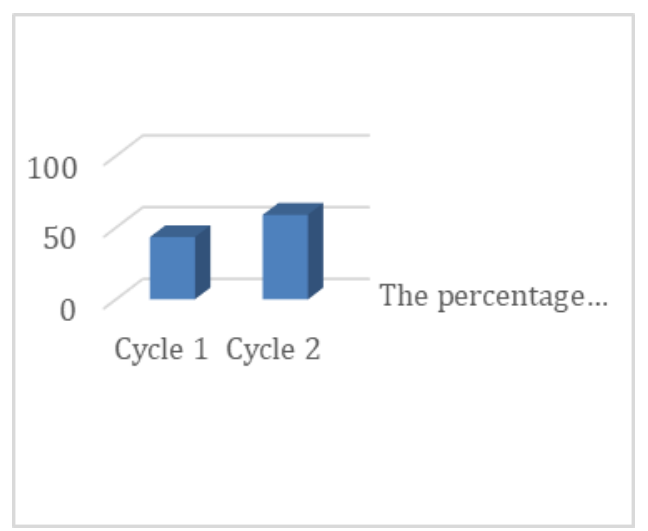

Figure 4: The Comparison of Students' Improvement 


\section{The Students' Responses towards Flashcard}

\section{in Learning Writing Descriptive Paragraph}

The researcher used questionnaire and interview to get the data of students' responses after the implementation of Flashcard in Learn writing descriptive paragraph. The result of the questionnaire can be seen in the following table:

Table 1: The Result of Questionnaire

\begin{tabular}{|c|c|c|c|}
\hline No. & Statements & $\begin{array}{l}\text { Percent } \\
\text { age }\end{array}$ & Category \\
\hline 1. & $\begin{array}{l}\text { You enjoy attending } \\
\text { the English class in } \\
\text { writing material by } \\
\text { using flashcard. }\end{array}$ & $84.61 \%$ & $\begin{array}{l}\text { Strongly } \\
\text { Agree }\end{array}$ \\
\hline 2. & $\begin{array}{l}\text { It is easier for you to } \\
\text { understand } \\
\text { material by } \\
\text { flashcarding }\end{array}$ & $83.07 \%$ & $\begin{array}{l}\text { Strongly } \\
\text { Agree }\end{array}$ \\
\hline 3. & $\begin{array}{l}\text { Flashcard } \\
\text { appropriate media in } \\
\text { learning writing for } \\
\text { you. }\end{array}$ & $82.56 \%$ & $\begin{array}{l}\text { Strongly } \\
\text { Agree }\end{array}$ \\
\hline 4. & $\begin{array}{l}\text { You are helped in } \\
\text { writing } \\
\text { paragraph by using } \\
\text { flashcard. }\end{array}$ & $88.20 \%$ & $\begin{array}{l}\text { Strongly } \\
\text { Agree }\end{array}$ \\
\hline 5. & $\begin{array}{l}\text { Learning with } \\
\text { flashcard is more enjoy } \\
\text { than learning uses } \\
\text { conventional method. }\end{array}$ & $87.69 \%$ & $\begin{array}{l}\text { Strongly } \\
\text { Agree }\end{array}$ \\
\hline 6. & $\begin{array}{l}\text { Your writing skill has } \\
\text { improved after using a } \\
\text { flashcard. }\end{array}$ & $81.02 \%$ & $\begin{array}{l}\text { Strongly } \\
\text { Agree }\end{array}$ \\
\hline 7. & $\begin{array}{l}\text { You want to use } \\
\text { flashcard again in the } \\
\text { next writing material }\end{array}$ & $81.02 \%$ & $\begin{array}{l}\text { Strongly } \\
\text { Agree }\end{array}$ \\
\hline
\end{tabular}

Based on that data, it showed that the students agreed if flashcard was an effective media for them in learn wriiting descriptive paragraph. This is also proven with one of students opinion that flashcard media was appropriate for him.

$[\mathrm{MH}]$ This media is appropriate with me sir, I am so interest with it because there is a picture in there. (Interview, 07/05/2020)

\section{CONCLUSION}

Learning a descriptive paragraph through flashcard can improve students' writing skill. It has proven with the average score of students which has improved. In accordance, the students' score who passed the minimum mastery of criteria (KKM) has also increased in each cycle. Then, the number of students who passed $\mathrm{KKM}$ is more than $80 \%$ in the last cycle. So, this study can be classified as successful action research. In addition, Almost of students gave positive responses to the use of flashcard in writing a descriptive paragraph, this proves that the implementation of flashcard is appropriate for them. 


\section{REFERENCES}

Apriliani, Ika. (2016) . A Study of Flash Cards in Teaching Vocabulary for Seventh Grade Students at Mts. Negeri II Surakarta in Academic Year of 2015/2016. Surakarta: IAIN Surakarta.

Arumawati, R. (2018). The Roles of the Teacher in Classroom Interaction in Writing Class at the Seventh Grade of SMPN 2 Colomadu on 2017 / 2018. 3, 28-37.

Aswinda Saputri, Nadia. (2017). "Improving Students' Speaking Skill Through Flash Card in Descriptive Paragraph at the Eighth Grade of Mts N Ngemplak Boyolali in Academic Year Of 2016/2017." Surakarta: IAIN Surakarta.

Brown, H. (2001). TEACHING by PRINCIPLES (An Interactive to Language Pedagogy) (Second). Pearson Longman.

Burns, A. (1999). Collaborative Action Research for English Language Teachers. Cambridge University Pers.

Burns, A. (2009). Doing Action Research in English Language Teaching (A Guide for Practitioners). Routledge. https://doi.org/10.4324/9780203863466

K. E. Suyanto, K. (2010). English for Young Learners. Bumi Aksara.

Mudiyatun, S. P. (2015). Meningkatkan
Kemampuan Berhitung Permulaan

Menggunakan Jaritmatika pada Anak

Kelompok A TK Tunas Harapan II Magelang. 4, 7-15.

Muttahidah, N. (2011). Improving Student' Vocabulary through Vocabulary Card. UIN Syarif Hidayatullah.

Oshima, A., \& Hogue, A. (2007). Introduction to Academic Writing (Third). Pearson Longman.

Peraturan Menteri Pendidikan Nasional Nomor 23 Tahun 2006:Indonesia, from: disdik.jabarprov.go.id

Pratiwi, K. D. (2012). Students' Difficulties in Writing English (A Study at The Third Semester Students of English Education Program At University of Bengkulu Academic Year 2011-2012). E Journal Universitas Bengkulu.

Rabiah, S. (2012). Language as a Tool for Communication and Cultural Reality Discloser. Presented in 1st International Conference on Media, Communication and Culture, 3, 1-18. https://orcid.org/0000-0002-1690-0025.

Sudijono, A. (2014). Pengantar Statistika Pendidikan. Rajawali Pers.

Tomtowi. (2019). The Attempt of Improving Activities and Writing Ability in Procedure Text through Demonstration Method. 6(2), 158-175. 